\title{
Evaluation of the Joint Master of Health Professions Education: A Distance Learning Program between Suez Canal University, Egypt, and Maastricht University, The Netherlands
}

Talaat $\mathbf{W}^{1}$, Van Dalen $\mathrm{J}^{3}$, Hamam $\mathbf{A}^{2}$, Khamis $\mathbf{N}^{1}$ and Abdel Nasser $\mathrm{A}^{\text {** }}$

${ }^{1}$ Medical Education Department, Faculty of Medicine, Suez Canal University, Egypt

${ }^{2}$ Orthopedics Department, Faculty of Medicine, Suez Canal University, Egypt

${ }^{3}$ Department: Skills laboratory, Maastricht University

\begin{abstract}
Objectives: To evaluate the implementation of the Joint Master of Health Professions Education (JMHPE) as a distance learning program as regards the e-learning process, the educational resources, the administrative process and the educational units of the JMHPE from the students', graduates' and faculty point of view.

Subjects and methods: A descriptive study was held to evaluate the JMHPE program (Process-Based, formative program evaluation). The target groups were all graduates of the Joint Master of Health Professions Education (71 graduates), fifth round students (82 students) and all planners and co-planners of the program (9 faculty). Two methods for data collection were used in this study, self administered questionnaires for the graduates, students and the Faculty, and review the JMHPE documents.

Results: Through the target groups' perspectives and documents review, the study resulted in an agreement among the majority of the JMHPE graduates and students who rated the program as "very good" or "excellent" as regards its relevance to their professions, meeting their expectations, being a challenging, professional distance learning program, meeting its educational objectives, its organization suitability, suitability of its duration to cover educational activities, in addition to its impact on increase in their knowledge in health professions education and acquitization of distance learning skills.

Enhancing capacity building and career development in Health Professions Education at all levels (national, regional, and international) was the most agreed upon point of strength ( $95 \%$ of graduates and $85 \%$ of students).

All of the graduates $(100 \%)$ and the majority of the students $(87.5 \%)$ mentioned their satisfaction from the JMHPE program as a whole, so all the graduates $(100 \%)$ and the majority of the students $(90 \%)$ would recommend it to their colleagues.

Dependence, reluctance and lack of commitment among some of the group members was the most agreed upon points of weakness ( $53 \%$ of the graduates and $87.5 \%$ of the students)

Conclusion: The Joint Masters of Health Professions Education is meeting its goals and objectives. Its theory is designed to achieve the intended outcomes and its operations make the theory effective. Being a distance learning program was an advantage for many of the program participants and facilitated their learning to a great extent. Most of the program participants were satisfied with the program and most of them also stated that they recommended the program to their peers.
\end{abstract}

Keywords: Health professions education; Distance learning; Formative process evaluation; Medical education; Group dynamics

\section{Introduction and Rationale}

As the quality of life of the human beings depends on the psychological and physical well-being, health professionals play a crucial role in helping people to prevent disease and restore health. The quality of the whole process of developing education for health professionals, educating these professionals and ensuring health care delivery deserves the full attention of both professionals and educators [1].

The Joint Master of Health Professions Education (JMHPE) offered by Suez Canal University and Maastricht University was developed by distance learning with the aim of providing participants with the intellectual means needed to attain JMHPE program objectives as: design, plan and implement a relevant course for health professionals based on rational principles of learning and instruction, and design, plan and implement an adequate process of evaluation and student assessment strategy. The rationale behind being a distance-learning, joint program is to combine the academic Maastricht experience with the practical Suez Canal experience while reducing costs and adding more relevance to health conditions in the area [1].

The JMHPE program is a 52 weeks credit-hour-based program. It is conducted entirely through distance learning. The program is focusing on the acquisition of knowledge and skills relevant to career development and research in health professions education. The program started to accept candidates from Health professions institutions in 2005 and five batches have been graduated [1].

*Corresponding author: Asmaa Abd El Nasser, Medical Education Department, Faculty of Medicine, Suez Canal University, Egypt. E-mail: dr.asmaashraf@gmail.com

Received May 15, 2013; Accepted September 10, 2013; Published September 18, 2013

Citation: Talaat W, Van Dalen J, Hamam A, Khamis N, Abdel Nasser A (2013) Evaluation of the Joint Master of Health Professions Education: A Distance Learning Program between Suez Canal University, Egypt, and Maastricht University, The Netherlands. Intel Prop Rights 2: 107. doi:10.4172/2375-4516.1000107

Copyright: (c) 2013 Yousef WT, et al. This is an open-access article distributed under the terms of the Creative Commons Attribution License, which permits unrestricted use, distribution, and reproduction in any medium, provided the original author and source are credited. 
Citation: Talaat W, Van Dalen J, Hamam A, Khamis N, Abdel Nasser A (2013) Evaluation of the Joint Master of Health Professions Education: A Distance Learning Program between Suez Canal University, Egypt, and Maastricht University, The Netherlands. Intel Prop Rights 2: 107. doi:10.4172/2375-4516.1000107

Page 2 of 5

Successful distance education systems involve interactivity between teacher and students, between students and the learning environment, and among students themselves, as well as active learning in the classroom. Although students feel that the accessibility of distance learning courses far outweighs the lack of dialogue, there is still a considerable concern about telecourses when compared to face-to-face classes [2].

Distance learning challenges accreditation by altering what we mean by "higher education institution" replacing or augmenting lecture halls with chat rooms, campuses with the World Wide Web, and communities of learning with the borderless networks of cyberspace [3].

As such program evaluation of distance learning programs is important to judge the value or worth of education and training programs [4] and its achievement of its outcomes.

Being a distance learning program, the JMHPE program is in much need for a comprehensive and documented program evaluation in order to fully understand how the program works, to assess its progress, to determine if the program is efficient and proactively predict and deal with any challenges that might face the program.

\section{Subjects and Methods}

A descriptive study was held to evaluate the JMHPE program (Process-Based Evaluation and formative program evaluation). The study was conducted at Suez Canal University International Center for training in Medical Education and Distance Learning. The target groups were all graduates of the Joint Master of Health Professions Education (71 graduates), fifth round students (82 students) who finished more than 4 units (about half of the program duration), and all planners and co-planners of the program ( 9 faculty).

Three types of data collection methods were used in this study, self administered questionnaires for graduates, students and block planners.

\section{Results}

The response rates were $84.5 \%$ among graduates (60 graduates out of 71 ), $49 \%$ among students (40 students out of 82 ), and $89 \%$ among faculty ( 8 faculty out of 9 ); the ninth being one of the authors.

For the geographical distribution of the JMHPE graduates and students, it was from different countries in the Middle East, Africa, North America, and Far East.

From the Middle East region was the most of the fellows from Egypt, Saudi Arabia and Yemen. But from other countries in the middle east like Sudan, Libya, Jordan, Pakistan, Syria, Iraq, Morocco, Qatar, Lebanon and Somalia. Also from Ghana, Canada, India and Philippines far from the Middle East.

$80 \%$ of the graduates and students rated the registration process of the program as excellent and the remaining $20 \%$ rated it as very good.

An agreement was found among the majority of the JMHPE graduates and students who rated the program as "very good" or "excellent" as regards its relevance to their professions, meeting their expectations, being a challenging, professional distance learning program, meeting its educational objectives, its organization, suitability of its duration to cover educational activities and the increase in their knowledge in health professions education field.

As for the main points of strength of the JMHPE; enhancing capacity building and career development in HPE at all levels (national, regional, and international) was the most agreed upon point of strength (95\% of graduates and $85 \%$ of students) Table 1 . According to the faculty the main points of strength; included flexibility, partnership with a European university, and dissemination of the important Medical Education field in the region.

On the other hand dependence, reluctance and lack of commitment among some of the group members were the most agreed upon points of weakness of the program according to $53 \%$ of the graduates and $87.5 \%$ of the students as shown in Table 2 . According to the faculty the main points of weakness; included Lack of cooperation between some fellows in doing the group assignments, strict pre-requisites for fellow's selections to join the JMHPE program and No elective courses in the program.

As regards using distance learning as a method of learning for a master in Health Professions Education, five of the block planners agreed that the distance learning is an appropriate medium for a master in Health Professions Education while the remaining see that a combination between distance and on campus learning is more appropriate.

Integrating interactive lectures supported by audiovisual aids is the main recommendation for improvement of the program mentioned by both graduates and students ( $68 \%$ and $87.5 \%$ respectively) as shown in Table 3. On the other hand, some of the block planners suggested adding other methods for assessment; as on-line exam (e.g. using MCQs) based on a determined specific time-limit, assessment of the presentation skills utilizing Video conferencing and using Mel- Web discussion for JMHPE students around certain topics not covered by the program but use complementary topics to the program. Regarding the educational units' organization $91 \%$ of the study population rated as "excellent" or "very good".

The JMHPE graduates' opinion concerning the most beneficial unit "Total quality management and accreditation in Health Professions Education" as the most beneficial unit (36.7\% of the graduates), followed by unit 8 "Measuring health professions competencies" $(15 \%$ of the graduates), followed by "Program Evaluation" and "Community Based Education incorporating Problem Based Learning" (10\% of the graduates).

The evaluation of the learning material from the graduates' and

\begin{tabular}{|c|c|c|c|c|}
\hline \multirow{2}{*}{ Points of strength } & \multicolumn{2}{|c|}{ Graduates } & \multicolumn{2}{|c|}{ Students } \\
\hline & No & $\%$ & No & $\%$ \\
\hline $\begin{array}{c}\text { Flexible and convenient } \\
\text { distance learning program. }\end{array}$ & 55 & 92 & 33 & 82.5 \\
\hline $\begin{array}{l}\text { Enhances capacity building } \\
\text { and career development in } \\
\text { HPE at all levels (national, } \\
\text { regional, and international). }\end{array}$ & 57 & 95 & 34 & 85 \\
\hline $\begin{array}{l}\text { Only credible certificate } \\
\text { (master degree) by distance } \\
\text { learning in HPE in the East- } \\
\text { ern Mediterranean Region. }\end{array}$ & 52 & 87 & 33 & 82.5 \\
\hline $\begin{array}{l}\text { Good selection of topics } \\
\text { that was relevant to the } \\
\text { program's goals. }\end{array}$ & 49 & 82 & 32 & 80 \\
\hline $\begin{array}{l}\text { Supportive and well qualified } \\
\text { director, staff and, manage- } \\
\text { ment team. }\end{array}$ & 50 & 83.3 & 20 & 50 \\
\hline
\end{tabular}

Table 1: Points of strength of the JMHPE program from the graduates' and students' point of view 
Citation: Talaat W, Van Dalen J, Hamam A, Khamis N, Abdel Nasser A (2013) Evaluation of the Joint Master of Health Professions Education: A Distance Learning Program between Suez Canal University, Egypt, and Maastricht University, The Netherlands. Intel Prop Rights 2: 107. doi:10.4172/2375-4516.1000107

Page 3 of 5

\begin{tabular}{|c|c|c|c|c|}
\hline \multirow{2}{*}{ Points of weakness } & \multicolumn{2}{|c|}{ Graduates } & \multicolumn{2}{|c|}{ Students } \\
\hline & No & $\%$ & No & $\%$ \\
\hline $\begin{array}{l}\text { Dependence, reluctance and } \\
\text { lack of commitment among } \\
\text { some of the group members. }\end{array}$ & 32 & 53 & 35 & 87.5 \\
\hline $\begin{array}{l}\text { References unclear, not } \\
\text { related to its assignments } \\
\text { and poor quality in units } 2 \text {, } \\
3 \text { and } 7 .\end{array}$ & 22 & 37 & 20 & 50 \\
\hline $\begin{array}{l}\text { Delay of the feedbacks } \\
\text { in some units especially } \\
\text { in units } 2,3,4 \text { and some } \\
\text { aspects in unit } 7 .\end{array}$ & 16 & 27 & 22 & 55 \\
\hline $\begin{array}{l}\text { Accessibility to learning } \\
\text { resources through the elec- } \\
\text { tronic library of Maastricht } \\
\text { University (eleum.unimass. } \\
\text { nl) very difficult and hard. }\end{array}$ & 15 & 25 & 6 & 15 \\
\hline
\end{tabular}

Table 2: Points of weakness of the JMHPE program from the graduates' and students' point of view

\begin{tabular}{|c|c|c|c|c|}
\hline \multirow{2}{*}{$\begin{array}{l}\text { Suggestions for improve- } \\
\text { ment }\end{array}$} & \multicolumn{2}{|c|}{ Graduates } & \multicolumn{2}{|c|}{ Students } \\
\hline & No & $\%$ & No & $\%$ \\
\hline $\begin{array}{l}\text { Adding Evidence Based } \\
\text { Medicine with topics as criti- } \\
\text { cal appraisal and meta-anal- } \\
\text { ysis and professionalism. }\end{array}$ & 35 & 58 & 17 & 42.5 \\
\hline $\begin{array}{l}\text { Using the Chat rooms for } \\
\text { students and block planners } \\
\text { at certain time. (Presched- } \\
\text { uled chat discussion). }\end{array}$ & 37 & 62 & 32 & 80 \\
\hline $\begin{array}{c}\text { Integration of some interac- } \\
\text { tive lectures supported by } \\
\text { audiovisual aids }\end{array}$ & 41 & 68 & 35 & 87.5 \\
\hline $\begin{array}{l}\text { Online short tests at the end } \\
\text { of each unit will be helpful in } \\
\text { reflecting the achievement } \\
\text { level of each member. }\end{array}$ & 34 & 57 & 27 & 67.5 \\
\hline $\begin{array}{l}\text { Change unit } 3 \text { (curriculum } \\
\text { analysis and course design) } \\
\text { to be more related to HPE } \\
\text { rather than general educa- } \\
\text { tion. }\end{array}$ & 41 & 68 & 21 & 52.5 \\
\hline
\end{tabular}

Table 3: Suggestions for improvement of the JMHPE program recommended by the study population

students' points of view showed that the majority of the graduates and students consider the learning material as relevant, valuable and readily available $76.6 \%$ to $97.5 \%$ rated these as "very good" or "excellent". However only, $56.6 \%$ of the graduates and $62.5 \%$ of the students consider the learning material frequency of update as "very good" or "excellent".

The evaluation of the JMHPE Suez Canal University website and blackboard from both graduates' and students' points of view. About $85 \%$ of the graduates rated the website as "very good" or "excellent" as regards ease of browsing and accessibility, while the students rating the same aspects of the website $92.5 \%$ and $95 \%$ respectively. On the other hand the evaluation of the JMHPE Maastricht University website and blackboard revealed that $53.3 \%$ of the graduates and $60 \%$ of the students rated the website as "very good" or "excellent" as regards ease of browsing and accessibility. only $50 \%$ of graduates and students rated the effectiveness of the electronic library of Suez Canal University website as" very good" or "excellent". On other hand only $28.3 \%$ of the graduates and $32.5 \%$ of rated the effectiveness of the electronic library of Maastricht University website as" very good" or "excellent".
Regarding the overall satisfaction about the program, all of the graduates $(100 \%)$ and the majority of the students $(87.5 \%)$ were satisfied with the JMHPE program as a whole that all the graduates (100\%) and the majority of the students (90\%) mentioned that they would recommend it to their colleagues (Figure 1).

\section{Discussion}

Time and geographical constraints make distance education a convenient and appealing option for many students. Also, distance education is a wave of the future, particularly with a recent increased emphasis on re-educating a workforce engaged in a lifetime of learning. Distance Learning (DL) has evolved to span a broad spectrum of technology uses, known variously as distributed education, distance education, and, more recently, e-learning to refer to online distance learning [5].

Evaluation of distance learning programs is a relatively new topic that is not yet comprehensively studied. Researches in such topic are few, especially in the field of health professions education. European universities known to offer degrees in health professions education were contacted at the beginning of this study, and no data were available about comprehensive evaluation of their programs.

Medical education is a specialized area of study that requires experience and knowledge of contemporary literature, research methods, curriculum planning, assessment of students, faculty development, evaluation of programs and curricula and the application of concepts of andragogy to all scenarios of teaching and learning.

Student satisfaction serves as an indicator of effective Distance Learning. While other measures are needed to assess student outcomes, regular checks on student satisfaction are especially informative, especially during the conversion phase of on-campus course work to the online environment [6].

Concerning the overall evaluation of the JMHPE program, 90\% ( $97.5 \%$ of students and $87 \%$ of the graduates) of the study population rated the program as extremely relevant to their needs as health professions educators and that it added very much to their knowledge and skills relevant to their career. The program has met its objectives as agreed upon by $86 \%$ of the study population $(95 \%$ of the students and $80 \%$ of the graduates) and it met the expectations of the learners as agreed upon by $92 \%$ of the study population ( $100 \%$ of the students and $87 \%$ of the graduates). The increasing levels of satisfaction (among

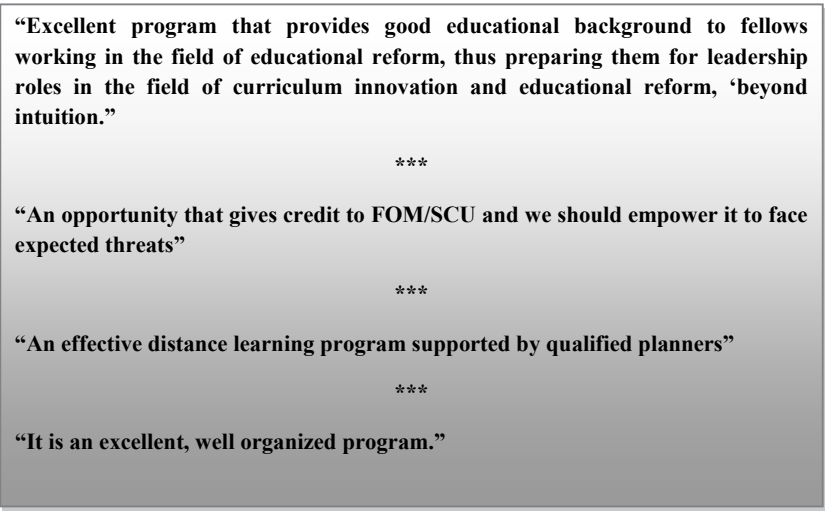

Figure 1: Quotations of the JMHPE block planners as regards their opinion about the program as a whole 

Distance Learning Program between Suez Canal University, Egypt, and Maastricht University, The Netherlands. Intel Prop Rights 2: 107. doi:10.4172/2375-4516.1000107

students versus graduates) highlight the continuous improvement that takes place in the program from year to year. These differences are not expected to be biased due to the student's still being under evaluation by the JMHPE management team as responses to the students' questions were anonymous.

Ninety five percent of the graduates and student $(100 \%$ of the graduates and $87.5 \%$ of the students) were satisfied with the JMHPE program as a whole. These satisfaction rates are consistent with the results of Bold [7] during the Evaluation of a Distance Learning Master's Degree in Family Studies, where 86\% of the 28 respondents reported a positive satisfaction rate in their first distance learning experience.

Relevance of the JMHPE program to health professions education, as agreed upon by $86.6 \%$ of the graduates and $97.5 \%$ of the students, as well as the potential of the program to enhance capacity building and career development, as agreed upon by $95 \%$ of the graduates and $85 \%$ of the students and might explain the interest of health professionals to join it.

The JMHPE program consists of 9 distance learning educational units completed during an annual 52 weeks (1 calendar year) which are as follows: Leadership and Management in Health Professions Education, The Nature of Student Learning and Learning Environment, Curriculum Analysis and Course Design, Development of Professional Skills: Acquisition, Training, and Assessment, Total Quality Management and Accreditation, Research Methodology and Bioethics, Program Evaluation, Measuring Health Professions Competencies, Community-Based Education incorporating Problem-Based Learning [1].

Comparing the units themes to other Health Professions Education Masters in reputable European Universities offering similar programs as Maastricht University, the Netherlands and Dundee University, United Kingdom, it was evident that the program units provide appropriate coverage of the important issues that are relevant for a career in the field of educational development and research for the health professions. However, more emphasis on curriculum design versus analysis was required according to the participants. The JMHPE also, has the advantage of being much more affordable in terms of fees and duration, where the other programs require longer time that ranges between 2 to 6 years. Yet this might be attributed to the existence of elective units for those students willing to proceed with more advanced levels as in Maastricht University MHPE or the presence of a wide menu of options from which the student chooses according to own needs as in the case of Dundee specialized health professions education units as anesthetists units, general practice, surgery...etc.

There are many inherent challenges to evaluating distance education courses, some of which include the fact that distance education courses are often the product of a team of professionals, including instructional designers, producer/directors, and technical specialists, working alongside faculty. The technology used in instruction is integral to the teaching and learning processes; therefore, it is important to assess the technology's effectiveness alongside the faculty member's teaching effectiveness. Because these two elements are intertwined, it is understandable that the evaluation process can become very complex [8].

The main educational resource in the case of distance electronic education is usually the electronic blackboard and/or the virtual classrooms. These resources noticed to be an integral part of the JMHPE website at Suez Canal University. The utility of the website and its related learning resources were evaluated from the learners' point of view. Easiness of accessibility and browsing was agreed upon by the majority of these groups of the study population $90 \%$ (about $92 \%$ of the students and $85 \%$ of the graduates). While as far the Maastricht University website and blackboard from the learners' point of view, easiness of accessibility and browsing was agreed upon by the graduates; $(53.3 \%)$ and $(45.2 \%)$ respectively, and by the students; $(60 \%)$ and (52.5\%) respectively. This could be explained by the difficulty in dealing with the sophisticated high technology of Maastricht versus Suez Canal websites. Yet, the fact that the Maastricht blackboard provides access to the main university library facilities including downloadable journals helps the students much with their studies. Baker [9] notes that the technological issues make it difficult to provide students with equal access to course materials in a distance learning program

Other logistics related to the mechanisms of enrolment in the JMHPE program like the registration processes and delivering the educational materials, helping students to get started as well as preparing and conducting the graduation ceremony were evaluated to be very satisfactory by the majority of the alumni as well as students.

The JMHPE has enabled the graduates as well as students to acquire and improve a scale of professional skills that are cardinal to their career. The acquired skills among graduates were that the program enhances mostly acquisition of distance learning skills and lifelong learning $(90 \%$ and $86.7 \%$ respectively). The importance of these findings are explained by Cheung $\mathrm{D}$ [10] who identified a number of forces that make lifelong learning a necessity; more jobs and careers require frequent learning; more people change jobs and careers often and need to learn additional skills and knowledge; people are living longer and find that learning adds quality to their life; and technological and economic progress should enable people to work shorter hours and allow them to have more time for other activities, including learning. According to students, the program enhances mostly acquisition of distance learning skills (92.5\%). The study in the JMHPE was considered the first experience for most of graduates and students with distance electronic education. The nature of the assignments that is dependent on critical appraisal of the literature is expected to be the main factor that led $85 \%$ of the students to mention critical thinking as acquired skills through the program.

As regards management skills and computer skills, $72.5 \%$ and $55 \%$ of students and $61 \%$ and $73.4 \%$ of graduates acquired efficient management and computer skills respectively. These findings are consistent with the results of Bold [7] where about $76 \%$ of the study population agreed that the skills developed during the program were distance learning, lifelong learning skills, computer skills as well as management skills.

The most evident points of strength of the JMHPE from the point of view of the students and graduates were that this program was the only credible certificate (Master Degree) by distance learning in Health Professions Education in the Eastern Mediterranean Region $(82.5 \%$ of the students and $87 \%$ of the graduates) as well as the flexibility of the program ( $82.5 \%$ of the students and $92 \%$ of the graduates) and the tangible evidence in capacity building of the learners $(85 \%$ of the students and $95 \%$ of the graduates). These results correlates with the main advantages of the distance learning as mentioned in literature, where there may be no alternatives for many students. Distance education offers flexibility and convenience, allowing geographically isolated students, and students with conflicting time commitments, to continue their education. A distance option also provides students with the opportunity to take two courses that are offered at the same time [11]. 
Citation: Talaat W, Van Dalen J, Hamam A, Khamis N, Abdel Nasser A (2013) Evaluation of the Joint Master of Health Professions Education: A Distance Learning Program between Suez Canal University, Egypt, and Maastricht University, The Netherlands. Intel Prop Rights 2: 107. doi:10.4172/2375-4516.1000107

Page 5 of 5

Again these findings are consistent with the results of Bold [7] where about $70 \%$ of the respondents agreed that the most important points of strength of the program are that the distance learning is saving time and Fuel in not having to drive the long distance to class, about $60 \%$ agreed that convenience or flexibility was cited by respondents as a best liked feature and $50 \%$ was also embedded in other answers as there was freedom to choose when and how to do work was liberating, not being tied to a classroom at a set time each week is nice.

One of the disadvantages of distance learning is that it may allow students to become lazy, using the online component as a crutch. Group projects may be more difficult for distance students as it may not be possible for students to meet face-to-face. Therefore, students may not be able to learn from each other as effectively. Furthermore, there may be less satisfaction without group interaction [12]. This disadvantage of distance learning programs constitutes the most evident point of weakness of the JMHPE program according to students and graduates is related to group dynamics, e.g., dependence, reluctance and lack of commitment among some of the group members $(87.5 \%$ of the students and $53 \%$ of the graduates). The barriers to communication in addition to the short time group members remain working together might jeopardize the normal phases of group dynamics up to the performing phase if not well guarded for. According to the majority of the faculty, the main point of weakness related to this point is the lack of cooperation between fellows in group work.

A major challenge of evaluation in distance education emanates from the very distance that exists between the learner and the teacher. This distance creates a situation whereby the control of the teacher is reduced, so the teacher's ability to completely have control over the evaluation processes is consequently reduced. It is imperative that the educator, in distance education, explores evaluation strategies that provide for increased ways in which the learner can be assessed and guided for individual growth and development [13].

One of the disadvantages of distance learning is that there is no live communication between the student and the instructor. Many instructors feel that the face-to face contact and the student/teacher interaction are critical to learning. Lack of this personal element also makes it more difficult for instructors to stimulate, or motivate students. Students can feel a sense of isolation and a lack of support [14].

Five of the block planners (62.5\%) agree that the distance learning is an appropriate medium for a Master in Health Professions Education while $37.5 \%$ of the planners see that face to face learning ensures interaction and guarantee comprehension and mutual understanding of needs and expectations. These findings are consistent with the results of Bold [7] where $70 \%$ of respondents mentioned that not having the face to face communication, the distance instructor being not readily available, or do not return "call" (e-mails) in a timely manner, lack of enough interaction with the professors, and more homework compared to regular classes are amongst the disadvantages of the distance learning programs.

\section{Conclusion}

The JMHPE has enabled the graduates as well as students to acquire and improve a scale of professional skills that are cardinal to their career. The acquired skills among graduates were that the program enhances mostly acquisition of distance learning skills and lifelong learning. According to students, the program enhances mostly acquisition of distance learning skills and critical thinking.

Finally, this study which is up to our knowledge the first study to evaluate a health professions education distance programs highlights the fact that the JMHPE is successfully accomplishing an important part of the mission of the Medical Education Department, Faculty of Medicine at Suez Canal University that states "improving the health professions education at the national, regional and international levels as evidenced by the increase in the relevant knowledge and skills of the participants".

This study was about the evaluation of the JMHPE process as a distance learning program. Further studies may focus on investigating the attainment of the program intermediate- term and longer- term outcomes which require longer follow up periods and larger number of graduates to reach an objective judgment of the outcome.

The study concludes that the Joint Masters of Health Professions Education is an effective credible masters program that helps many health professionals' gain and master essential skills in health professions education that are essential for their careers. Being a distance learning program was an advantage for many of the program participants and facilitated their learning to a great extent. Most of the program participants were satisfied with the program and most of them also stated that they recommended the program to their peers.

We may also conclude that the JMHPE is a sustainable program. Evidence on this include the increasing number of applicants from round to round, the expansion of the program to include fellows from different regions and different countries and self-dependence of the program as regards its resources (financial, technical, and physical).

\section{References}

1. Education Brochure of Joint Master of Health Professions Education, Suez Canal University, Egypt.

2. Jonassen D (1992) Applications and limitations of hypertext technology for distance learning. Distance Learning Workshop, Armstrong Laboratory, and San Antonio, TX, USA

3. McNabb J (1994) Telecourse effectiveness: Findings in the current literature. Tech Trends 39: 39-40.

4. Sponder BM (1990) Distance education in rural Alaska: An overview of teaching and learning practices in audioconference courses. University of Alaska Press, USA.

5. Eaton A, Orwig G (2001) New technologies for education. Libraries Unlimited Englewood, Colarado, USA.

6. Caffarella RS (2001) Planning Programs for Adult Learners (Second Edition) Wiley, John \& Sons, USA 225-238.

7. Bold M (2003) Development and Evaluation of a Distance Learning Master's Degree in Family Studies. Online Journal of Distance Learning Administration 8: 1-12.

8. Golden O (2003) The program manager's guide to evaluation. Administration for Children and Families (USDHHS), USA.

9. Baker RK (2003) A framework for design and evaluation of Internet-based distance learning courses: Phase one-framework justification, design and evaluation. Online Journal of Distance Learning Administration 6.

10. Cheung D (1998) Developing a student evaluation instrument for distance teaching. Distance Education 19: 23-42.

11. Harrington CF, Reasons SG (2005) Online Student Evaluation of Teaching for Distance Education: A Perfect Match? University of Southern Indiana. The J Educ Online 2:1-12.

12. Volery T, Lord D (2000) Critical success factors in online education. International Journal of Educational Management 14: 216-223.

13. Garrison DR (1989) Understanding distance education: A framework for the future. Routledge, London, UK.

14. Daniel JS (1996) Mega-Universities and Knowledge Media: Technology Strategies for Higher Education. Kogan Page Limited, London, UK. 